\title{
1 Herpes simplex virus entry by a non-conventional endocytic 2 pathway
}

3

4 Giulia Tebaldi, Suzanne M. Pritchard, and Anthony V. Nicola ${ }^{1}$

5 Department of Veterinary Microbiology and Pathology, College of Veterinary Medicine,

6 Washington State University, Pullman, WA, USA

7

8 Running title: HSV ENTRY AND Rab GTPases

9

10

$11{ }^{1}$ Correspondence: anthony.nicola@wsu.edu 
Herpes simplex virus 1 (HSV-1) causes significant morbidity and mortality in humans

43 worldwide. HSV-1 enters epithelial cells via an endocytosis mechanism that is low $\mathrm{pH}-$

44 dependent. However, the precise intracellular pathway has not been identified, including the

45 compartment where fusion occurs. In this study, we utilized a combination of molecular and

46 pharmacological approaches to better characterize HSV entry by endocytosis. HSV-1 entry was

47 unaltered in both cells treated with siRNA to Rab5 or Rab7 and cells expressing dominant-

48 negative forms of these GTPases, suggesting entry is independent of the conventional endo-

49 lysosomal network. The fungal metabolite brefeldin A (BFA) and the quinoline compound

50 Golgicide A (GCA) inhibited HSV-1 entry via beta-galactosidase reporter assay and impaired

51 incoming virus transport to the nuclear periphery, suggesting a role for trans Golgi network

52 (TGN) functions and retrograde transport in HSV entry. Silencing of Rab9 or Rab11 GTPases,

53 which are involved in the retrograde transport pathway, resulted in only a slight reduction in

54 HSV infection. Together these results suggest that HSV enters host cells by an intracellular route

55 independent of the lysosome-terminal endocytic pathway. 


\section{IMPORTANCE}

65 HSV-1, the prototype alphaherpesvirus, is ubiquitous in the human population and causes

66 lifelong infection that can be fatal in neonatal and immunocompromised individuals. HSV enters

67 many cell types by endocytosis, including epithelial cells, the site of primary infection in the

68 host. The intracellular itinerary for HSV entry remains unclear. We probed the potential

69 involvement of several Rab GTPases in HSV-1 entry, and suggest that endocytic entry of HSV-1

70 is independent of the canonical lysosome-terminal pathway. A non-traditional endocytic route

71 may be employed, such as one that intersects with the TGN. These results may lead to novel

72 targets for intervention.

73

\section{KEYWORDS}

75 herpes simplex virus 1, viral entry, Rab GTPases, endocytosis, TGN, retrograde transport. 


\section{INTRODUCTION}

94 Herpes simplex viruses (HSVs) are ubiquitous human pathogens that cause lifelong latent

95 infections and significant morbidity and mortality all around the world. In immunocompetent

96 patients HSV can cause cold sores and genital infections. Serious outcomes include blindness

97 and fatal neonatal infections. In immune-compromised persons, HSV infects diverse organ

98 systems including the respiratory and gastrointestinal tracts and the central nervous system (1-3).

99 HSV-1 is internalized by endocytosis into epithelial cells, the site of lytic replication, by a

100 multistep process that requires low $\mathrm{pH}$. HSV enters some cells, including human neurons, by a

$101 \mathrm{pH}$-independent penetration at the plasma membrane (4-9). HSV entry is quite rapid.

102 Immediately after infection, enveloped viral particles are detected in smooth-walled vesicles

103 adjacent to the host cell plasma membrane (10). Treatment of cells with either hypertonic (0.3 M

104 sucrose) medium or with medium that inhibits host cell ATP synthesis specifically blocks both

105 receptor-mediated endocytosis and HSV entry into CHO-receptor and epithelial cells (4).

106 Importantly, these treatments do not interfere with non-endocytic entry into cells that support

107 fusion of herpesvirions with the cell surface $(4,11,12)$. The enveloped virion traffics through the

108 host cell vesicular system until it arrives in a compartment of the appropriate low $\mathrm{pH}$, triggering

109 membrane fusion and penetration of the capsid into the cytosol $(9,13,14)$. Macropinocytosis-

110 like and phagocytosis-like processes have been implicated (4-6, 10, 15-18). However, the precise

111 intra-vesicular route taken and its regulation remains unclear.

112 Most animal viruses enter cells by endocytosis, and endosomal low $\mathrm{pH}$ is the most

113 common cellular trigger of enveloped virus fusion (19). Inhibitors of vesicle acidification block

114 HSV entry at an early, post-binding step $(4,10)$. Endosomes are the first acidic compartments in 
115 the endocytic pathway (20). Vesicular $\mathrm{pH}$ gradually decreases from 6.2 to approximately 5.0 as

116 cargo moves from the early endosome (EE) to the late endosome (LE) and finally to the

117 lysosome $(9,10,21)$. The endo-lysosomal system represents a complex and highly dynamic

118 network of interacting and interconnected compartments, which are critical for host cell

119 homeostasis (22). This lysosome-terminal endocytic pathway is a very common route for viruses

120 entering cells via endocytosis (23-26). When cells either lack a required cellular gD-binding

121 receptor for entry or the virus itself is entry-defective, HSV-1 is degraded, presumably in

122 lysosomes $(4,10,27)$. We theorized that HSV transits the common lysosome-terminal endocytic

123 pathway during viral entry.

125 Rab (Ras-related protein in brain) (28) proteins are master regulators of intracellular vesicle

126 transport events, including vesicle formation, actin- and tubulin-dependent vesicle movement,

127 and the interconnection of endosomal and autophagy pathways (29-32). Many pathogens hijack

128 Rab GTPase functions upon invasion (28, 33-36). Rab proteins are involved in several stages of

129 the viral replication cycle, including entry via endocytosis, viral assembly and egress, and viral

130 glycoprotein trafficking (37). Rab5 is located at the cytoplasmic surface of the plasma membrane

131 and on early endosomes. Thus, it is involved in the formation of clathrin-coated vesicles (CCVs),

132 selectively regulating the transport of newly endocytosed vesicles from the plasma membrane to

133 early endosomes. Rab5 mediates the homotypic fusion between early endosomes (38-40). Rab7

134 is a late endosome-/lysosome-associated small GTPase, the only lysosomal Rab protein

135 identified to date. It regulates the transport from EE to LE and LE to lysosomes. Rab7 also plays

136 an important role in autophagy (41-45). Rab9 is located on the late endosome, and it mediates

137 late endosome-to-trans-Golgi network transport $(46,47)$. Rab11 is associated with the trans- 
138 Golgi network (TGN), post-Golgi vesicles, and recycling compartments. It regulates transport

139 along the recycling pathway, from recycling endosomes to the cell surface, and the retrograde

140 transport from the perinuclear endocytic recycling compartment (ERC) to the TGN $(41,48-51)$.

141 Here, a combination of molecular and pharmacological approaches was used to better

142 characterize the mechanism of HSV-1 entry, including the intracellular pathway of incoming

143 HSV. Specifically, we used siRNAs and dominant-negative mutants to investigate the

144 involvement of Rab GTPases in HSV-1 endocytosis. Neither Rab5 nor Rab7 played a major role

145 in HSV-1 endosomal trafficking. Rab9 and Rab11 may play a slight role. Inhibitor results

146 suggest that retrograde transport and TGN function may play important roles during HSV entry

147 by endocytosis.

\section{RESULTS AND DISCUSSION}

\section{Knockdown of Rab5 or Rab7 does not inhibit HSV infectivity}

151 HSV enters cells by an endocytic pathway that is incompletely characterized. Rab GTPases are

152 central to the conventional lysosome-terminal endocytosis pathway that is utilized by a multitude

153 of cargoes, including entering viruses. Rab5 selectively regulates the transport of newly

154 endocytosed cargo from the plasma membrane to the EE. Rab7 is critical for EE to LE traffic

$155(39,42)$. Chinese hamster ovary $(\mathrm{CHO})$ cells expressing a gD-receptor such as herpesvirus entry

156 mediator (HVEM), are well-characterized model cell types for HSV entry by endocytosis (10,

157 52, 53). CHO-HVEM cells were transfected with siRNA sequences targeting Rab5 or Rab7, or

158 with a scrambled siRNA sequence. Downregulation was verified by Western blot analysis (Fig.

159 1A). As determined by densitometry, host Rab5 and Rab7 were reduced by 60 and $93 \%$,

160 respectively. Rab downregulation was further confirmed by microscopic analysis of fluorescent 
161 transferrin or LysoTracker in siRNA transfected cells. Knockdown of Rab5 or Rab7 altered the

162 subcellular distribution of transferrin and LysoTracker in CHO-HVEM cells (Fig. 2A-B).

163 First, the effect of siRNAs was tested on the entry of a control virus, vesicular stomatitis

164 virus (VSV). Endocytic entry of VSV is Rab5-dependent and has also been reported as Rab7-

165 independent $(37,54)$. The siRNA-transfected cells were infected with VSV Indiana strain for 6

$166 \mathrm{hr}$ (MOI of 0.5). Infectivity was quantitated by indirect immunofluorescence microscopy. As

167 expected, VSV infection of CHO-HVEM cells was inhibited by siRNA to Rab5 (Fig. 1B).

168 Conversely, VSV infection was not significantly inhibited by siRNA to Rab7 (Fig. 1B). These

169 results validate the transfection protocol for down-regulating the production of target proteins in

170 CHO-HVEM cells. Down-regulation of Rab5 resulted in inhibition of infection by a virus that

171 traverses a Rab-5-dependent entry pathway. To address whether HSV entry requires the

172 conventional, lysosome-terminal endosomal pathway, Rab5 or Rab7 was knocked down in

173 CHO-HVEM cells and HSV KOS infectivity at 6 hr p.i. was quantitated. Neither Rab5 nor Rab7

174 silencing resulted in a significant decrease in HSV-1 infection (Fig. 1C).

175 To assess further the roles of Rab5 and Rab7 in HSV entry and infection, CHO-HVEM

176 cells were stably transfected with dominant-negative (DN) Rab5 S34N or Rab7 T22N. As

177 expected, VSV infection of Rab5 S34N-expressing cells was reduced relative to control cells,

178 while infection of Rab7 T22N-expressing cells was less affected (Fig. 1D). HSV-1 entry into

179 CHO-HVEM cells, as measured by the reporter assay, was not inhibited by the expression of DN

180 forms of Rab5 or Rab7 (Fig. 1E). Together, the results in Figure 1 suggest that Rab5 and Rab7

181 GTPases do not play a major role in HSV entry and that virus-cell fusion may occur in an

182 intracellular compartment that is distinct from the conventional endosomal route. The majority of

183 viruses that enter cells via endocytosis use the lysosome-terminal endocytic pathway; however, 
184 several viruses have evolved different and sophisticated mechanisms to hijack other aspects of

185 the host endocytic network (23). Lymphocytic choriomeningitis (LCMV) enters cells via LE 186 bypassing the EE (55). Mouse polyomavirus (PyV) travels from the EE to the recycling 187 endosome and then to the ER (56). Papillomavirus takes a retrograde transport pathway to the 188 TGN (57-59).

\section{Inhibitors of TGN function impair HSV entry}

191 To probe further the involvement of mildly acidic compartments in HSV entry, in the context of 192 a non-conventional vesicular pathway, we utilized pharmacologic inhibitors of the trans-Golgi 193 network, which has a $\mathrm{pH}$ of $\sim 6(60,61)$. The $\mathrm{pH}$ of the $\mathrm{CHO}$ cell TGN is $5.95(62)$, which is 194 consistent with the $\mathrm{pH}$ that induces conformational change in HSV-1 gB (13, 63-66). Brefeldin A 195 (BFA) is a small hydrophobic compound produced by toxic fungi (67). It triggers the absorption 196 of the cis/medial/trans portion of the Golgi apparatus (68) into the ER through inhibition of the 197 cis-Golgi ArfGEF (guanine nucleotide exchange factor) (GBF1). GBF1 is responsible for 198 maintaining Golgi structure and enabling anterograde and retrograde traffic through the Golgi 199 and TGN (69). BFA's effects are not limited to the Golgi. BFA also promotes the tubulation of 200 early endosomes, the lysosome and TGN (67) whose components redistribute with the recycling 201 endosomal system $(67,70,71)$. Golgicide A (GCA) is a potent and highly specific inhibitor of

202 GBF1. Inhibition of GBF1 function arrests the retrograde transport of Shiga toxin from EE/RE to 203 the TGN $(69,72)$.

204 The effect of BFA and GCA on HSV-1 entry was measured by a beta-galactosidase 205 reporter assay. CHO-HVEM cells harbor the lacZ gene under an HSV-inducible promoter. BFA 
207 as much as $46 \%$ and $79 \%$, respectively (Fig. 3A, B). To extend these results, we investigated the

208 role of the TGN in delivery of incoming HSV-1 K26GFP capsids to the nucleus during entry

209 (Fig. 3C). In HSV-infected CHO-HVEM cells, the bulk of the GFP signal is detected at or near

210 the nucleus by $2.5 \mathrm{~h}$ p.i (Fig. 3C). In the continued presence of BFA or GCA, GFP-tagged

211 capsids were not effectively transported to the nuclear periphery (Fig. 3C). Instead, the bulk of

212 GFP-tagged viral particles appeared to be trapped at sites distinct from the nucleus. These results

213 were obtained in the presence of the protein synthesis inhibitor cycloheximide to ensure that GFP

214 signal was from input virions only. This also suggests that newly synthesized viral factors do not

215 affect the TGN-dependence of entry. Together, the results suggest that the TGN and the

216 retrograde transport pathway play an important role during HSV entry by endocytosis.

217 Nonenveloped viruses such as simian virus 40 (SV40), human polyomaviruses (73), adeno-

218 associated virus (74, 75), and human papillomavirus (HPV) (57-59), take advantage of the

219 retrograde transport route during entry. HPV entry is inhibited by BFA at a post-fusion step (76).

220 The possibility remains that BFA inhibits a post-fusion step in HSV entry as well.

\section{Role of Rab9 and Rab11 in HSV-1 entry}

223 Since retrograde transport and/or the TGN play a potential role in endocytic entry of HSV, we

224 investigated Rab GTPases that control retrograde transport to the TGN. Rab9 mediates 225 retrograde transport from the late endosome to the TGN $(46,47)$, and Rab11 controls retrograde 226 transport from early/recycling endosomes-to-TGN (EE/RE-to-TGN) (50, 72). Other viruses take 227 advantage of the recycling $(45,77)$ and TGN $(57,78)$ compartments. To test the roles of Rab9 or 228 Rab11 in HSV entry, CHO-HVEM cells were treated with appropriate siRNAs. Knockdown of 229 Rab9 or Rab11 was confirmed by Western blot (Fig. 4A). As determined by densitometry, Rab9 
230 and Rab11 were reduced by 75 and $83 \%$, respectively. As further confirmation, in Rab9 or

231 Rab11-depleted cells, fluorescently labelled LysoTracker or transferrin, respectively was

232 detected in enlarged vesicles relative to control cells (Fig. 2A-B). HSV-1 KOS was added to

233 cells (MOI of 3) and infectivity was measured by indirect immunofluorescence at 6 hr p.i. (Fig.

234 4B). Silencing of Rab9 or Rab11 resulted in a slight decrease in HSV-1 infectivity (Fig. 4B).

235 Under the conditions tested, the results suggest that these host cell proteins may play a small role

236 in HSV entry. There is also likely significant entry that occurs independent of Rab9 and Rab11

237 functions. A TGN role in HSV entry that is independent of these Rab GTPases is also possible.

238 A small molecule inhibitor was tested to probe further the role of retrograde trafficking in

239 HSV entry. Retro-2 blocks retrograde traffic from EE to the TGN, and consequently inhibits

240 cytosolic uptake of Shiga and ricin toxins $(58,79-82)$. Micromolar concentrations of retro-2

241 inhibits entry of human papillomavirus 16 , BK virus, JC virus, and SV40, and transduction by

242 adeno-associated virus serotype 2, all of which rely on retrograde transport mechanisms $(58,73$,

243 75). Retro-2 treatment of CHO-HVEM cells had no inhibitory effect on HSV-1 entry as

244 measured by the beta-galactosidase reporter assay (Fig. 5A). As a control for retro-2 activity, the

245 effect on plaque formation was assessed. Retro 2.1, a derivative of retro-2, inhibits HSV-2

246 plaque formation on Vero cells, likely at the stage of assembly or egress (83). Retro-2 was

247 effective at inhibiting HSV-1 infectivity as measured by plaque formation (Fig. 5B), suggesting

248 that retro-2 can exhibit inhibitory activity in our hands. Retro-2 inhibits the wrapping and egress

249 of vaccinia virus particles, suggesting that the retrograde pathway is important for these steps of

250 the vaccinia replication cycle (84). HSV entry is insensitive to retro-2 yet sensitive to inhibition

251 by both BFA and GCA. This suggests that HSV entry is distinct from Shiga toxin trafficking,

252 although it may share overlapping features. 
The retrograde transport system is complex and selective. It relies on numerous tethering

254 factors, small GTPases, and SNARES $(85,86)$. Other Rab proteins like Rab 6a, Rab 6IP, Rab 30

255 and the Rab $7 b$ isoform mediate retrograde traffic from the endocytic compartment to the TGN

$256(59,87)$. The overlapping and varied functions of distinct isoforms of the same Rab protein (88)

257 reflects the complexity of processes in which these proteins are involved $(28,89,90)$. Notably,

258 retrograde trafficking occurs from different endocytic compartments (EE, RE, LE) to the TGN

259 and to the Golgi apparatus. There is a rapidly expanding network of proteins and processes

260 involved in this interplay (91). The retromer, a conserved cytoplasmic protein complex, plays a

261 central role in retrograde transport from endosome-to-Golgi, as well as from endosome-to-

262 plasma membrane $(57,92,93)$. HPV16 directly exploits the retromer at the early or late

263 endosome and traffics to the TGN/Golgi via the retrograde pathway during cell entry (58). In

264 contrast to HSV-1 (Fig. 5A), HPV16 entry is blocked by retro-2 in a concentration-dependent

265 manner.

266 Overall this study suggests that HSV-1 entry by endocytosis is independent of the Rab

267 GTPases that govern the conventional EE to LE to lysosome pathway. TGN function might be

268 involved during HSV-1 low pH endocytosis entry in epithelial cells. It will be important to

269 confirm the present results in more physiologically relevant cell types such as primary human

270 keratinocytes. GCA, which blocks retrograde trafficking to the TGN, reduced HSV-1 infection

271 of CHO-receptor cells by $\sim 79 \%$. Further research is necessary to define the GCA- and BFA-

272 sensitive nature of HSV entry. Importantly, alternate endocytic entry pathways may also

273 function, even in the same cell type. The results reported here provide context for further

274 characterization of HSV-1 entry by endocytosis and set the stage for identification of the

275 intracellular site of membrane fusion. 


\section{MATERIALS AND METHODS}

\section{Cells}

279 CHO-HVEM (M1A) cells (94), provided by R. Eisenberg and G. Cohen, University of

280 Pennsylvania, are stably transformed with the human HVEM (or HveA) gene and contain the

281 Escherichia coli lacZ gene under the control of the HSV-1 ICP4 gene promoter. CHO-HVEM

282 cells were propagated in Ham's F12 nutrient mixture (Gibco/Life Technologies) supplemented

283 with $10 \%$ FBS, $150 \mu \mathrm{g}$ of puromycin (Sigma-Aldrich, St. Louis, MO, USA)/ml, and $250 \mu \mathrm{g}$ of

284 G418 sulfate (Thermo Fisher Scientific, Fair Lawn, NJ, USA)/ml. Cells were sub-cultured in

285 nonselective medium prior to use in all experiments. Vero cells (American Type Culture

286 Collection, Manassas, VA) were propagated in Dulbecco's modified Eagle's medium (DMEM)

287 (ThermoFisher Scientific, Grand Island, NY) supplemented with 10\% fetal bovine serum

288 (Atlanta Biologicals, Atlanta, GA), respectively. Baby hamster kidney (BHK) cells were 289 propagated in DMEM high nutrient mixture (Gibco/Life Technologies) supplemented with 5\%

290 fetal bovine serum.

\section{Viruses}

293 HSV-1 strain KOS (95) (provided by Priscilla Schaffer, Harvard Medical School) was 294 propagated and titered on Vero cells. Vesicular stomatitis virus (VSV) Indiana strain, provided 295 by Douglas Lyles, Wake Forest University, was titered on BHK cells and CHO-HVEM cells. 296 HSV-1 KOS K26 GFP contains green fluorescent protein (GFP) fused to the N-terminus of the 297 VP26 capsid protein (96) (provided by Prashant Desai, Johns Hopkins University). It was 298 propagated and titrated on Vero cells. 


\section{Transient transfection}

301 CHO-HVEM cells were grown in 24-well plates to $70 \%$ confluence. Culture medium was

302 removed, and the cells were transfected with siCtrl (sc-37007), siRab5A (sc-36344), siRab7A

303 (sc-29460), siRab9A (sc-41831) or siRab11A (sc-36341) (Santa Cruz Biotechnology) using

304 Lipo3000 transfection reagent (Thermo Fisher). Briefly, 60 pmol of siRNA was mixed with 1.5

$305 \mu$ Lipo3000 in $50 \mu$ of serum-free OPTIMEM (Gibco Life Technologies) for 15 min at room

306 temperature. Serum-free OPTIMEM medium was added to a final volume of $250 \mu$, and the

307 transfection reaction was added to cells for $5 \mathrm{~h}$ at $37^{\circ} \mathrm{C}$. The transfection mixture was replaced

308 with medium supplemented with $10 \% \mathrm{FBS}$, and cultures were incubated for 24 or $48 \mathrm{~h}$ at $37^{\circ} \mathrm{C}$.

\section{SDS-PAGE and Western blotting}

311 At 24 or $48 \mathrm{~h}$ post-transfection, protein cell extracts were prepared by RIPA lysis buffer (50 mM

312 Tris-HCl, EDTA $2 \mathrm{mM}, 150 \mathrm{mM} \mathrm{NaCl}$, and 1\% NP-40; pH 8) supplemented with cOmplete,

313 Mini, EDTA-free Protease Inhibitor Cocktail (Roche). Total protein concentration was calculated

314 with the BCA Protein Assay Kit (Pierce). Cell lysates were separated by SDS-PAGE on 4-20\%

315 Tris-glycine gels (Novex). Following transfer to nitrocellulose by electroblotting, membranes

316 were blocked and incubated with antibodies to $\alpha$-Tubulin (Sigma T9026), Rab5 (Abcam

317 ab18211), Rab7 (Abcam ab137029), Rab9 (Invitrogen MA3-067), or Rab11 (Invitrogen 71-

318 5300). Secondary antibody conjugated with horseradish peroxidase (Sigma) was added, followed

319 by enhanced chemiluminescence substrate (SuperSignal West Dura Extended Duration, Thermo 320 Scientific). 
HSV infectivity measured by immunofluorescence microscopy

323 At 24 or $48 \mathrm{~h}$ post-transfection, HSV-1 KOS (MOI of 3) or VSV (MOI of 0.5) was added to cell

324 monolayers grown on glass coverslips in 24-well culture dishes. At $6 \mathrm{~h}$ p.i., cultures were

325 washed with PBS, fixed in ice-cold methanol and blocked with 1\% BSA in PBS. Anti-ICP4

326 MAb H1A021 or monoclonal Ab to VSV glycoprotein G (P5D4, Sigma) was added for $1 \mathrm{~h}$

327 followed by Alexa Fluor 488-labeled goat anti-mouse IgG (Invitrogen) for $30 \mathrm{~min}$. Nuclei were

328 counterstained with $5 \mathrm{ng} / \mathrm{ml}$ of DAPI. Coverslips were mounted on slides with Fluoromount G

329 and visualized with a Leica DMi8 Fluorescence microscope at 10X magnification. Cells were

330 counted with ImageJ. Three independent experiments were performed with three replicates per

331 experiment.

332

\section{Cells transfected with dominant-negative Rab GTPase plasmids}

334 Dominant-negative Rab5 (S34N) or Rab7 (T22N) or mock plasmids expressing the sequence of

335 interest and Turbo RFP (Red Fluorescent Protein) gene under control of elongation factor, and

336 the hygromycin-resistance gene under control of a mouse phosphoglycerate kinase 1 promoter

337 were synthesized and sequenced by VectorBuilder (Chicago, Illinois). CHO-HVEM cells in a 25

$338 \mathrm{~cm}^{2}$ flask were grown to $70 \%$ confluence and transfected with $7.5 \mu \mathrm{g}$ of DNA using the

339 Lipofectamine 3000 Transfection Kit (Invitrogen) according to the manufacturer's instructions.

340 At $5 \mathrm{~h}$ post-transfection, the transfection mixture was replaced with complete F12 medium. At 24

$341 \mathrm{~h}$ post-transfection, medium was replaced with complete F12 supplemented with $500 \mu \mathrm{g} / \mathrm{ml}$

342 Hygromycin B (Invitrogen). When cells in a control untransfected flask were killed by

343 Hygromycin B ( 72 h), the transfected cells were subcultured in selection medium. The stably

344 transfected cells were passaged $>6$ times under constant selection prior to use in viral entry

345 experiments. For experiments, transfected or mock-transfected CHO-HVEM cells in 
346 Hygromycin B were plated and kept under Hygromycin selection until attachment. Following

347 cell attachment, selective medium was removed and replaced with complete medium for $24 \mathrm{~h}$.

349 VSV plaque assay

350 Transfected cells in Hygromycin B were added to 6-well plates. Following cell attachment, 351 selective medium was removed and replaced with complete medium. After $24 \mathrm{~h}$, VSV was added 352 and titered by limiting dilution. At $1 \mathrm{~h}$ p.i., the inoculum was removed and replaced with warm 2 $353 \mathrm{ml} 2 \%$ carboxymethyl cellulose in F12 medium with 2\% FBS (CMC). At 48 h p.i., 2 ml of 10\% 354 formalin was layered onto the $\mathrm{CMC}$ for $2 \mathrm{~h}$ at room temperature. The overlay was removed, and 355 fixed cells were washed with water. Crystal violet was added for $30 \mathrm{~min}$ at room temperature. 356 Cells were rinsed with water. Plaques were visualized with a Leica stereoscope.

\section{Beta-galactosidase reporter assay of HSV-1 entry}

359 HSV-1 KOS was added (MOI 1) in the continued presence of drugs. At 6 hr p.i., $0.5 \%$ 360 IGEPAL (Sigma-Aldrich) was added to lyse the cells. Chlorophenol red-beta-D361 galactopyranoside (Roche Diagnostics, Indianapolis, IN) substrate was added to cell lysates, and

362 the beta-galactosidase activity was read at $595 \mathrm{~nm}$ with an ELx808 microtiter plate reader 363 (BioTek Instruments, Winooski, VT, United States). Beta-galactosidase activity indicates 364 successful viral entry (97).

\section{Transferrin and LysoTracker uptake assays}

367 CHO-HVEM cells were grown in 24-well plates to $70 \%$ confluence and then transfected with 368 siRab5A, siRab7A, siRab9A, or siRab11A as described above. For transferrin uptake, at $24 \mathrm{~h}$ 
369 post-transfection, cultures were washed twice and replenished with serum-free F12 medium for

$37080 \mathrm{~min}$ total at $37^{\circ} \mathrm{C}$ replacing the medium every $40 \mathrm{~min}$. Cultures were incubated on ice at $4^{\circ} \mathrm{C}$

371 for $40 \mathrm{~min}$. Transferrin Texas Red Conjugate (100 $\mu \mathrm{g} / \mathrm{ml})$ (Invitrogen T2875) was added to the

372 wells for $50 \mathrm{~min}$ at $4^{\circ} \mathrm{C}$. Cells were washed to remove unbound transferrin, and then serum-

373 containing F12 medium was added at $37^{\circ} \mathrm{C}$ for $10 \mathrm{~min}$. For LysoTracker uptake, at $24 \mathrm{~h}$ post-

374 transfection, $100 \mathrm{nM}$ LysoTracker Red DND-99 (Invitrogen L7528) in complete F12 medium

375 was added for $30 \mathrm{~min}$ at $37^{\circ} \mathrm{C}$. Cultures were washed twice with PBS and fixed with $3 \%$

376 paraformaldehyde-PBS at $37^{\circ} \mathrm{C}$ for $10 \mathrm{~min}$. Fixed cells were washed twice with PBS, quenched

377 with $50 \mathrm{mM} \mathrm{NH}_{4} \mathrm{Cl}$ at room temperature for $10 \mathrm{~min}$, and then permeabilized with $0.1 \%$ Triton $\mathrm{X}$ -

378100 in PBS for $10 \mathrm{~min}$. Nuclei were counterstained with $5 \mathrm{ng} / \mathrm{ml}$ of 4,6-diamidino-2-

379 phenylindole dihydrochloride (DAPI; Roche). Coverslips were mounted on slides with

380 Fluoromount G (Electron Microscopy Sciences, Hatfield, PA) and visualized with a Leica DMi8

381 fluorescence microscope at $100 \mathrm{X}$ magnification.

382

\section{Effect of Golgi inhibitors on HSV-1 entry}

384 Confluent cell monolayers grown in 96-well plates were pretreated with a range of 385 concentrations of brefeldin A (BFA, EMD Millipore CAS 20350-15-6) or Golgicide A (GCA, 386 EMD Millipore CAS 1139889-93-2) for $20 \mathrm{~min}$ or with retro-2 (Sigma CAS 1429192-00-6) for 4 $387 \mathrm{~h}$ at $37^{\circ} \mathrm{C}$. Control samples were treated with vehicle DMSO. HSV-1 KOS was added and 388 method for beta-galactosidase reporter assay was followed. 
391 Sub-confluent CHO-HVEM cell monolayers grown on coverslips in 24-well plates were treated 392 with $2 \mu \mathrm{g} / \mathrm{ml} \mathrm{BFA}, 10 \mu \mathrm{M} \mathrm{GCA}$ or $50 \mathrm{mM} \mathrm{NH}_{4} \mathrm{Cl}$ in the presence of $0.5 \mathrm{mM}$ cycloheximide for $39320 \mathrm{~min}$ at $37^{\circ} \mathrm{C}$. HSV-1 K26GFP (MOI of 100) was added for $2.5 \mathrm{~h}$ in the continued presence of 394 agents. Cultures were washed twice with PBS and fixed with 3\% paraformaldehyde-PBS at $39537^{\circ} \mathrm{C}$ for $10 \mathrm{~min}$. Fixed cells were washed twice with $\mathrm{PBS}$, quenched with $50 \mathrm{mM} \mathrm{NH}_{4} \mathrm{Cl}$ at 396 room temperature for $10 \mathrm{~min}$, and then permeabilized with $0.1 \%$ Triton X-100 in PBS for 10 397 min. Nuclei were counterstained with $5 \mathrm{ng} / \mathrm{ml}$ of 4,6-diamidino-2-phenylindole dihydrochloride 398 (DAPI; Roche). Coverslips were mounted on slides with Fluoromount G (Electron Microscopy 399 Sciences, Hatfield, PA) and visualized with a Leica DMi8 fluorescence microscope at 100X 400 magnification.

402 HSV plaque assay

403 CHO-HVEM cells in 24 well plates were pre-treated with $50 \mu \mathrm{M}$ Retro-2 (Sigma) for $4 \mathrm{~h}$ at $40437^{\circ} \mathrm{C}$. HSV-1 KOS ( $100 \mathrm{PFU} /$ well) was added in the continued presence of drug. At $24 \mathrm{~h}$ p.i., 405 cells were fixed with ice-cold methanol and acetone $(2: 1$ ratio $)$ for $20 \mathrm{~min}$ at $-20^{\circ} \mathrm{C}$ and air-dried 406 and assayed for HSV plaque formation. Cells were stained with rabbit polyclonal antibody to 407 HSV, HR50 (Fitzgerald Industries, Concord, MA), washed thrice with PBS and incubated with 408 1:200 dilution of goat anti-rabbit IgG conjugated with horseradish peroxidase (Thermo Fisher 409 Scientific) for $1 \mathrm{~h}$ at room temperature. Following three washes with PBS, 4-chloro-1-naphtol 410 (Sigma) substrate was added and plaques were visualized with a Leica stereoscope.

\section{Statistical analysis}


413 Student's t-test with one tail distribution was used for infectivity experiments. Data are shown as

414 geometric means with errors bars representing \pm s.e.m. Significance is indicated as $* \mathrm{P}<0.05$,

$415 \quad * * \mathrm{P}<0.00005$.

416

417 ACKNOWLEDGMENTS

418 This work was supported by Public Health Service grant AI119159 (A.V.N.) from the National

419 Institute of Allergy and Infectious Diseases. We thank Gary Cohen, Roselyn Eisenberg, Douglas

420 Lyles, and Priscilla Schaffer for generous gifts of reagents. We thank Massaro Ueti for the use of

421 the fluorescence microscope and members of the Nicola laboratory for helpful discussions and

422 suggestions.

\section{REFERENCES}

1. Roizman B, Knipe, DM., Whitley, RJ. 2013. Herpes simplex viruses, 6th ed. Lippincott Williams \& Wilkins,.

2. Kennedy PG, Steiner I. 2013. Recent issues in herpes simplex encephalitis. J Neurovirol 19:346-350.

3. Liesegang TJ. 2001. Herpes simplex virus epidemiology and ocular importance. Cornea

4. Nicola AV, McEvoy AM, Straus SE. 2003. Roles for endocytosis and low pH in herpes simplex virus entry into HeLa and Chinese hamster ovary cells. Journal of virology 77:5324-5332.

5. Nicola AV, Hou J, Major EO, Straus SE. 2005. Herpes simplex virus type 1 enters human

444 8. Koyama AH, Uchida T. 1989. The effect of ammonium chloride on the multiplication of 445

6. Sayers CL, Elliott G. 2016. Herpes Simplex Virus 1 Enters Human Keratinocytes by a Nectin-1-Dependent, Rapid Plasma Membrane Fusion Pathway That Functions at Low Temperature. J Virol 90:10379-10389.

7. Lycke E, Hamark B, Johansson M, Krotochwil A, Lycke J, Svennerholm B. 1988. Herpes simplex virus infection of the human sensory neuron. An electron microscopy study. Arch Virol 101:87-104. herpes simplex virus type 1 in Vero cells. Virus Res 13:271-281. 
9. Nicola AV. 2016. Herpesvirus Entry into Host Cells Mediated by Endosomal Low pH. Traffic 17:965-975.

10. Nicola AV, Straus SE. 2004. Cellular and viral requirements for rapid endocytic entry of herpes simplex virus. Journal of virology 78:7508-7517.

11. Pastenkos G, Lee B, Pritchard SM, Nicola AV. 2018. Bovine Herpesvirus 1 Entry by a Low-pH Endosomal Pathway. J Virol 92.

12. Miller JL, Weed DJ, Lee BH, Pritchard SM, Nicola AV. 2019. Low-pH Endocytic Entry of the Porcine Alphaherpesvirus Pseudorabies Virus. J Virol 93.

13. Dollery SJ, Delboy MG, Nicola AV. 2010. Low pH-induced conformational change in herpes simplex virus glycoprotein B. J Virol 84:3759-3766.

14. Weed DJ, Nicola AV. 2017. Herpes simplex virus Membrane Fusion. Adv Anat Embryol Cell Biol 223:29-47.

15. Devadas D, Koithan T, Diestel R, Prank U, Sodeik B, Dohner K. 2014. Herpes simplex virus internalization into epithelial cells requires $\mathrm{Na}+\mathrm{H}+$ exchangers and $\mathrm{p} 21$-activated kinases but neither clathrin- nor caveolin-mediated endocytosis. J Virol 88:13378-13395.

16. Clement C, Tiwari V, Scanlan PM, Valyi-Nagy T, Yue BYJT, Shukla D. 2006. A novel role for phagocytosis-like uptake in herpes simplex virus entry. The Journal of cell biology 174:1009-1021.

17. Petermann P, Haase I, Knebel-Morsdorf D. 2009. Impact of Rac1 and Cdc42 signaling during early herpes simplex virus type 1 infection of keratinocytes. J Virol 83:9759-9772.

18. Rahn E, Petermann P, Hsu MJ, Rixon FJ, Knebel-Morsdorf D. 2011. Entry pathways of herpes simplex virus type 1 into human keratinocytes are dynamin- and cholesteroldependent. PloS one 6:e25464.

19. Nicola AV, Aguilar HC, Mercer J, Ryckman B, Wiethoff CM. 2013. Virus entry by endocytosis. Adv Virol 2013:469538.

20. Fuchs R, Ellinger, A., Pavelka, M., Peterlik, M., and Mellman, I. 1987. Endocytic coated vesicles do not exhibit ATP-dependent acidification in vitro. J Cell Biol 105.

21. Klumperman J, Raposo G. 2014. The complex ultrastructure of the endolysosomal system. Cold Spring Harbor perspectives in biology 6:a016857-a016857.

22. van Weering JRT, Verkade P, Cullen PJ. 2012. SNX-BAR-Mediated Endosome Tubulation is Co-ordinated with Endosome Maturation. Traffic 13:94-107.

23. Cossart P, Helenius A. 2014. Endocytosis of viruses and bacteria. Cold Spring Harb Perspect Biol 6.

480 25. Staring J, Raaben M, Brummelkamp TR. 2018. Viral escape from endosomes and host detection at a glance. J Cell Sci 131.

26. Lozach PY, Huotari J, Helenius A. 2011. Late-penetrating viruses. Curr Opin Virol 1:3543.

27. Campadelli-Fiume G, Arsenakis M, Farabegoli F, Roizman B. 1988. Entry of herpes simplex virus 1 in BJ cells that constitutively express viral glycoprotein $D$ is by endocytosis and results in degradation of the virus. J Virol 62:159-167.

28. Pylypenko O, Hammich H, Yu IM, Houdusse A. 2018. Rab GTPases and their interacting protein partners: Structural insights into Rab functional diversity. Small GTPases 9:2248. 
490 29. Ao X, Zou L, Wu Y. 2014. Regulation of autophagy by the Rab GTPase network. Cell Death Differ 21:348-358.

493

30. Hutagalung AH, Novick PJ. 2011. Role of Rab GTPases in membrane traffic and cell physiology. Physiol Rev 91:119-149.

31. Stenmark H, Olkkonen VM. 2001. The Rab GTPase family. Genome Biol 2:REVIEWS3007.

32. Elgner F, Hildt E, Bender D. 2018. Relevance of Rab Proteins for the Life Cycle of Hepatitis C Virus. Front Cell Dev Biol 6:166.

33. De Franceschi N, Hamidi H, Alanko J, Sahgal P, Ivaska J. 2015. Integrin traffic - the update. J Cell Sci 128:839-852.

34. Militello R, Colombo MI. 2013. Small GTPases as regulators of cell division. Commun Integr Biol 6:e25460.

35. Numrich J, Ungermann C. 2014. Endocytic Rabs in membrane trafficking and signaling. Biol Chem 395:327-333.

504

36. van ljzendoorn SC, Mostov KE, Hoekstra D. 2003. Role of rab proteins in epithelial membrane traffic. Int Rev Cytol 232:59-88.

37. Spearman P. 2018. Viral interactions with host cell Rab GTPases. Small GTPases 9:192201.

38. Gorvel JP, Chavrier P, Zerial M, Gruenberg J. 1991. rab5 controls early endosome fusion in vitro. Cell 64:915-925.

39. Bucci C, Parton RG, Mather IH, Stunnenberg H, Simons K, Hoflack B, Zerial M. 1992. The small GTPase rab5 functions as a regulatory factor in the early endocytic pathway. Cell 70:715-728.

40. McLauchlan H, Newell J, Morrice N, Osborne A, West M, Smythe E. 1998. A novel role for Rab5-GDI in ligand sequestration into clathrin-coated pits. Curr Biol 8:34-45.

41. Feng Y, Press B, Wandinger-Ness A. 1995. Rab 7: an important regulator of late endocytic membrane traffic. J Cell Biol 131:1435-1452.

42. Vitelli R, Santillo M, Lattero D, Chiariello M, Bifulco M, Bruni CB, Bucci C. 1997. Role of the small GTPase Rab7 in the late endocytic pathway. J Biol Chem 272:4391-4397.

43. Gutierrez MG, Munafo DB, Beron W, Colombo MI. 2004. Rab7 is required for the normal progression of the autophagic pathway in mammalian cells. J Cell Sci 117:26872697.

44. Jager S, Bucci C, Tanida I, Ueno T, Kominami E, Saftig P, Eskelinen EL. 2004. Role for Rab7 in maturation of late autophagic vacuoles. J Cell Sci 117:4837-4848.

45. Liu C-C, Zhang Y-N, Li Z-Y, Hou J-X, Zhou J, Kan L, Zhou B, Chen P-Y. 2017. Rab5 and Rab11 Are Required for Clathrin-Dependent Endocytosis of Japanese Encephalitis Virus in BHK-21 Cells. Journal of virology 91:e01113-01117.

46. Lombardi D, Soldati T, Riederer MA, Goda Y, Zerial M, Pfeffer SR. 1993. Rab9 functions in transport between late endosomes and the trans Golgi network. EMBO J 12:677-682.

47. Dintzis SM, Pfeffer SR. 1990. The mannose 6-phosphate receptor cytoplasmic domain is not sufficient to alter the cellular distribution of a chimeric EGF receptor. EMBO J 9:7784.

48. Zhang Y-N, Liu Y-Y, Xiao F-C, Liu C-C, Liang X-D, Chen J, Zhou J, Baloch AS, Kan L, Zhou B, Qiu H-J. 2018. Rab5, Rab7, and Rab11 Are Required for Caveola-Dependent 
Endocytosis of Classical Swine Fever Virus in Porcine Alveolar Macrophages. Journal of virology 92:e00797-00718.

49. Ullrich O, Reinsch S, Urbe S, Zerial M, Parton RG. 1996. Rab11 regulates recycling through the pericentriolar recycling endosome. J Cell Biol 135:913-924.

50. Wilcke M, Johannes L, Galli T, Mayau V, Goud B, Salamero J. 2000. Rab11 regulates the compartmentalization of early endosomes required for efficient transport from early endosomes to the trans-golgi network. J Cell Biol 151:1207-1220.

51. Welz T, Wellbourne-Wood J, Kerkhoff E. 2014. Orchestration of cell surface proteins by Rab11. Trends Cell Biol 24:407-415.

52. Gianni T, Campadelli-Fiume G, Menotti L. 2004. Entry of herpes simplex virus mediated by chimeric forms of nectin1 retargeted to endosomes or to lipid rafts occurs through acidic endosomes. J Virol 78:12268-12276.

53. Campadelli-Fiume G, Cocchi F, Menotti L, Lopez M. 2000. The novel receptors that mediate the entry of herpes simplex viruses and animal alphaherpesviruses into cells. Rev Med Virol 10:305-319.

54. Sieczkarski SB, Whittaker GR. 2003. Differential requirements of Rab5 and Rab7 for endocytosis of influenza and other enveloped viruses. Traffic 4:333-343.

57. DiMaio D, Burd CG, Goodner K. 2015. Riding the R Train into the Cell. PLoS Pathog 11:e1005036.

58. Lipovsky A, Popa A, Pimienta G, Wyler M, Bhan A, Kuruvilla L, Guie MA, Poffenberger retromer as a cellular entry factor for human papillomavirus. Proc Natl Acad Sci U S A 110:7452-7457.

59. Sapp MJ. 2013. HPV virions hitchhike a ride on retromer complexes. Proc Natl Acad Sci U S A 110:7116-7117.

60. Casey JR, Grinstein S, Orlowski J. 2010. Sensors and regulators of intracellular pH. Nat Rev Mol Cell Biol 11:50-61.

61. Paroutis P, Touret N, Grinstein S. 2004. The pH of the secretory pathway: measurement, determinants, and regulation. Physiology (Bethesda) 19:207-215.

62. Demaurex N, Furuya W, D'Souza S, Bonifacino JS, Grinstein S. 1998. Mechanism of acidification of the trans-Golgi network (TGN). In situ measurements of pH using retrieval of TGN38 and furin from the cell surface. J Biol Chem 273:2044-2051.

63. Dollery SJ, Wright CC, Johnson DC, Nicola AV. 2011. Low-pH-dependent changes in the conformation and oligomeric state of the prefusion form of herpes simplex virus glycoprotein B are separable from fusion activity. J Virol 85:9964-9973.

64. Siekavizza-Robles CR, Dollery SJ, Nicola AV. 2010. Reversible conformational change in herpes simplex virus glycoprotein B with fusion-from-without activity is triggered by mildly acidic pH. Virol J 7:352. 
65. Weed DJ, Pritchard SM, Gonzalez F, Aguilar HC, Nicola AV. 2017. Mildly Acidic pH Triggers an Irreversible Conformational Change in the Fusion Domain of Herpes Simplex Virus 1 Glycoprotein B and Inactivation of Viral Entry. J Virol 91.

74. Bantel-Schaal U, Hub B, Kartenbeck J. 2002. Endocytosis of adeno-associated virus type

66. Weed DJ, Dollery SJ, Komala Sari T, Nicola AV. 2018. Acidic pH Mediates Changes in Antigenic and Oligomeric Conformation of Herpes Simplex Virus gB and Is a Determinant

67. Lippincott-Schwartz J, Yuan L, Tipper C, Amherdt M, Orci L, Klausner RD. 1991. Brefeldin A's effects on endosomes, lysosomes, and the TGN suggest a general mechanism for regulating organelle structure and membrane traffic. Cell 67:601-616.

68. Huang S, Wang Y. 2017. Golgi structure formation, function, and post-translational modifications in mammalian cells. F1000Res 6:2050.

69. Saenz JB, Sun WJ, Chang JW, Li J, Bursulaya B, Gray NS, Haslam DB. 2009. Golgicide A reveals essential roles for GBF1 in Golgi assembly and function. Nat Chem Biol 5:157165.

70. Klausner RD, Donaldson JG, Lippincott-Schwartz J. 1992. Brefeldin A: insights into the control of membrane traffic and organelle structure. J Cell Biol 116:1071-1080.

71. Lippincott-Schwartz J, Yuan LC, Bonifacino JS, Klausner RD. 1989. Rapid redistribution of Golgi proteins into the ER in cells treated with brefeldin A: evidence for membrane cycling from Golgi to ER. Cell 56:801-813.

72. Mallard F, Tang BL, Galli T, Tenza D, Saint-Pol A, Yue X, Antony C, Hong W, Goud B, Johannes L. 2002. Early/recycling endosomes-to-TGN transport involves two SNARE complexes and a Rab6 isoform. J Cell Biol 156:653-664.

73. Nelson CD, Carney DW, Derdowski A, Lipovsky A, Gee GV, O'Hara B, Williard P, DiMaio D, Sello JK, Atwood WJ. 2013. A retrograde trafficking inhibitor of ricin and Shiga-like toxins inhibits infection of cells by human and monkey polyomaviruses. mBio 4:e0072900713.

75. Nonnenmacher ME, Cintrat JC, Gillet D, Weber T. 2015. Syntaxin 5-dependent retrograde transport to the trans-Golgi network is required for adeno-associated virus transduction. J Virol 89:1673-1687.

76. Laniosz V, Dabydeen SA, Havens MA, Meneses PI. 2009. Human papillomavirus type 16 infection of human keratinocytes requires clathrin and caveolin-1 and is brefeldin a sensitive. J Virol 83:8221-8232.

77. Vale-Costa S, Amorim MJ. 2016. Recycling Endosomes and Viral Infection. Viruses 8:64.

78. Day PM, Thompson CD, Schowalter RM, Lowy DR, Schiller JT. 2013. Identification of a role for the trans-Golgi network in human papillomavirus 16 pseudovirus infection. J Virol 87:3862-3870.

79. Stechmann B, Bai SK, Gobbo E, Lopez R, Merer G, Pinchard S, Panigai L, Tenza D, Raposo G, Beaumelle B, Sauvaire D, Gillet D, Johannes L, Barbier J. 2010. Inhibition of retrograde transport protects mice from lethal ricin challenge. Cell 141:231-242.

80. Nicolas V, Lievin-Le Moal V. 2020. Small Trafficking Inhibitor Retro-2 Disrupts the Microtubule-Dependent Trafficking of Autophagic Vacuoles. Front Cell Dev Biol 8:464. 
81. Forrester A, Rathjen SJ, Daniela Garcia-Castillo M, Bachert C, Couhert A, Tepshi L, Pichard S, Martinez J, Munier M, Sierocki R, Renard HF, Augusto Valades-Cruz C, Dingli F, Loew D, Lamaze C, Cintrat JC, Linstedt AD, Gillet D, Barbier J, Johannes L. 2020. Functional dissection of the retrograde Shiga toxin trafficking inhibitor Retro-2. Nat Chem Biol 16:327-336.

82. Farhan H. 2020. Rendezvous of Retro-2 at the ER. Nat Chem Biol 16:229-230.

83. Dai W, Wu Y, Bi J, Wang J, Wang S, Kong W, Barbier J, Cintrat JC, Gao F, Jiang Z, Gillet D, Su W, Jiang C. 2018. Antiviral Effect of Retro-2.1 against Herpes Simplex Virus Type 2 In Vitro. J Microbiol Biotechnol 28:849-859.

84. Sivan G, Weisberg AS, Americo JL, Moss B. 2016. Retrograde Transport from Early Endosomes to the trans-Golgi Network Enables Membrane Wrapping and Egress of Vaccinia Virus Virions. J Virol 90:8891-8905.

85. Bonifacino JS, Rojas R. 2006. Retrograde transport from endosomes to the trans-Golgi network. Nat Rev Mol Cell Biol 7:568-579.

86. Schindler C, Chen Y, Pu J, Guo X, Bonifacino JS. 2015. EARP is a multisubunit tethering complex involved in endocytic recycling. Nat Cell Biol 17:639-650.

87. Zulkefli KL. 2017. Role of Rab11 and Rab30 in regulating the endosome-trans-Golgi networkUniversity of Melbourne.

88. Schwartz SL, Cao C, Pylypenko O, Rak A, Wandinger-Ness A. 2007. Rab GTPases at a glance. J Cell Sci 120:3905-3910.

89. Pfeffer SR. 2005. Structural clues to Rab GTPase functional diversity. J Biol Chem 280:15485-15488.

90. Diekmann Y, Seixas E, Gouw M, Tavares-Cadete F, Seabra MC, Pereira-Leal JB. 2011. Thousands of rab GTPases for the cell biologist. PLoS Comput Biol 7:e1002217.

91. Johannes L, Popoff V. 2008. Tracing the retrograde route in protein trafficking. Cell 135:1175-1187.

92. Lu L, Hong W. 2014. From endosomes to the trans-Golgi network. Semin Cell Dev Biol 31:30-39.

93. Seaman MN. 2012. The retromer complex - endosomal protein recycling and beyond. J Cell Sci 125:4693-4702.

94. Montgomery RI, Warner MS, Lum BJ, Spear PG. 1996. Herpes simplex virus-1 entry into cells mediated by a novel member of the TNF/NGF receptor family. Cell 87:427-436.

95. Macdonald SJ, Mostafa HH, Morrison LA, Davido DJ. 2012. Genome sequence of herpes simplex virus 1 strain KOS. J Virol 86:6371-6372.

96. Desai P, Person S. 1998. Incorporation of the green fluorescent protein into the herpes simplex virus type 1 capsid. J Virol 72:7563-7568.

658

97. Delboy MG, Patterson JL, Hollander AM, Nicola AV. 2006. Nectin-2-mediated entry of a syncytial strain of herpes simplex virus via $\mathrm{pH}$-independent fusion with the plasma membrane of Chinese hamster ovary cells. Virology Journal 3.

\section{FIGURE LEGENDS}


663 Figure 1. Role of Rab5 and Rab7 on HSV entry and infection. (A) The knockdown efficiency

664 of Rab5 or Rab7 was determined by Western blotting. CHO-HVEM cells (-) were transiently

665 transfected with either control, Rab5 or Rab7 siRNAs for $24 \mathrm{~h}$ or $48 \mathrm{~h}$. Cell lysates were reacted

666 with anti-Rab5 or anti-Rab7 antibody specific for the indicated proteins. $\alpha$-Tubulin was used as

667 an internal loading control. (B, C) CHO-HVEM cells (-) were transiently transfected with

668 control, Rab5 or Rab7 siRNAs for 24 h or 48 h. Control, Rab5, or Rab7 siRNA-treated cells

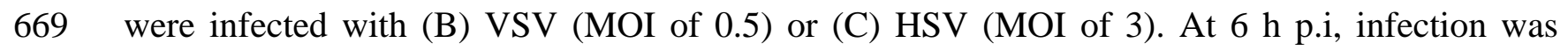

670 detected by quantitating VSV G-positive cells or HSV ICP4-positive cells via indirect

671 immunofluorescence microscopy. At least 500 cells per cover slip were counted. Values are the

672 mean $\pm \mathrm{SE}$ of three independent experiments ${ }^{*} \mathrm{P} \leq 0.05$. (D, E) Effect of DN forms of Rab5 or

673 Rab7 on HSV entry. CHO-HVEM cells were stably transfected with control, Rab5 S34N or

674 Rab7 T22N plasmids. Cells were infected with (D) VSV Indiana (120 PFU/well) or (E) HSV-1

675 KOS (MOI 0.5-1). At 44 h p.i., VSV infectivity was measured by plaque assay. At 6 h p.i., HSV

676 entry was measured by beta-galactosidase reporter assay. Infectivity in control cells was set to

$677100 \%$. Each experiment was performed in at least triplicate. Data shown are the averages \pm SE of

678 at least two independent experiments $* * \mathrm{P} \leq 0.00005$.

680 Figure 2. Effect of Rab knockdowns on the subcellular distribution of transferrin and

681 LysoTracker. CHO-HVEM cells were transfected with siRNAs specific for (A, B) Rab5, Rab7,

682 (A) Rab11 or (B) Rab9. Downregulation of Rab5 and Rab7 was verified by Western blot (see

683 Fig. 1). Downregulation of Rab9 and Rab11 was verified by Western blot (see Fig. 4). (A)

684 Transferrin-Texas Red $(100 \mu \mathrm{g} / \mathrm{ml})$ was bound to cells at $4^{\circ} \mathrm{C}$, and then cultures were shifted to

$68537^{\circ} \mathrm{C}$ for $10 \mathrm{~min}$. (B) $100 \mathrm{nM}$ LysoTracker Red DND-99 was added for $30 \mathrm{~min} 37^{\circ} \mathrm{C}$. Cells were 
686 fixed, and nuclei were counterstained with DAPI. The contrast of panels in B was adjusted 687 equivalently with Canvas.

689 Figure 3. Golgi-inhibitors brefeldin A and Golgicide A impair HSV entry. CHO-HVEM

690 cells were pretreated for 20 min with the indicated concentrations of (A) BFA or (B) GCA.

691 HSV-1 strain KOS was added (MOI of 1) for $6 \mathrm{~h}$ in the constant presence of drug. Beta692 galactosidase activity at $595 \mathrm{~nm}$ is indicative of successful HSV entry. Beta-galactosidase 693 activity in the absence of drug was set to 100\%. (C) CHO-HVEM cells on coverslips were 694 infected with HSV-1 K26GFP (MOI of 100) and concurrently exposed to $2 \mu \mathrm{g} / \mathrm{ml} \mathrm{BFA,} 10 \mu \mathrm{M}$ 695 GCA or $50 \mathrm{mM} \mathrm{NH4Cl}$ for $2.5 \mathrm{~h}$. Cells were fixed, and nuclei were stained with DAPI (blue). In 696 untreated cells, the majority of incoming capsids (green) were detected at or near the nucleus. In 697 BFA, GCA, and control NH4Cl, treated cells, capsids were trapped in the cell periphery.

Figure 4. Effects of Rab9 and Rab11 knockdown on HSV entry and infection. (A) The

700 knockdown efficiency of Rab9 or Rab11 was determined by Western blotting. CHO-HVEM 701 cells (-) were transiently transfected with either control, Rab9 or Rab11 siRNAs for 24 h. Cell 702 lysates were reacted with anti-Rab9 or anti-Rab11 antibody specific for the indicated proteins. $\alpha-$ 703 Tubulin was used as an internal loading control. (B) CHO-HVEM cells (-) were transiently 704 transfected with control, Rab9 or Rab11 siRNAs for 24 h. Control, Rab9, or Rab11 siRNA705 treated cells were infected with HSV (MOI of 3). At $6 \mathrm{~h} \mathrm{p.i,} \mathrm{infection} \mathrm{was} \mathrm{detected} \mathrm{by}$ 706 quantitating HSV ICP4-positive cells via indirect immunofluorescence microscopy. At least 500 707 cells per cover slip were counted. Values are the mean \pm SE of three independent experiments $708 \quad * \mathrm{P} \leq 0.05$ 
710 Figure 5. Effects of Retro-2 on HSV entry and infection. (A) CHO-HVEM cells were

711 pretreated with the indicated concentrations of retro- 2 for $4 \mathrm{~h}$. HSV-1 strain KOS was added

712 (MOI 1) for $6 \mathrm{~h}$ in the presence of drug. Beta-galactosidase activity in the absence of drug was

713 set to $100 \%$ entry. (B) Vero cells were pretreated for $4 \mathrm{~h}$ with $50 \mu \mathrm{M}$ retro-2. HSV-1 KOS (100

714 PFU/well) was added for $24 \mathrm{~h}$ at $37^{\circ} \mathrm{C}$. Plaque formation in the absence of drug was set to $100 \%$.

715 Each experiment was performed in quadruplicate. Data shown are the averages \pm SE of three

716 independent experiments $* \mathrm{P} \leq 0.05$. 

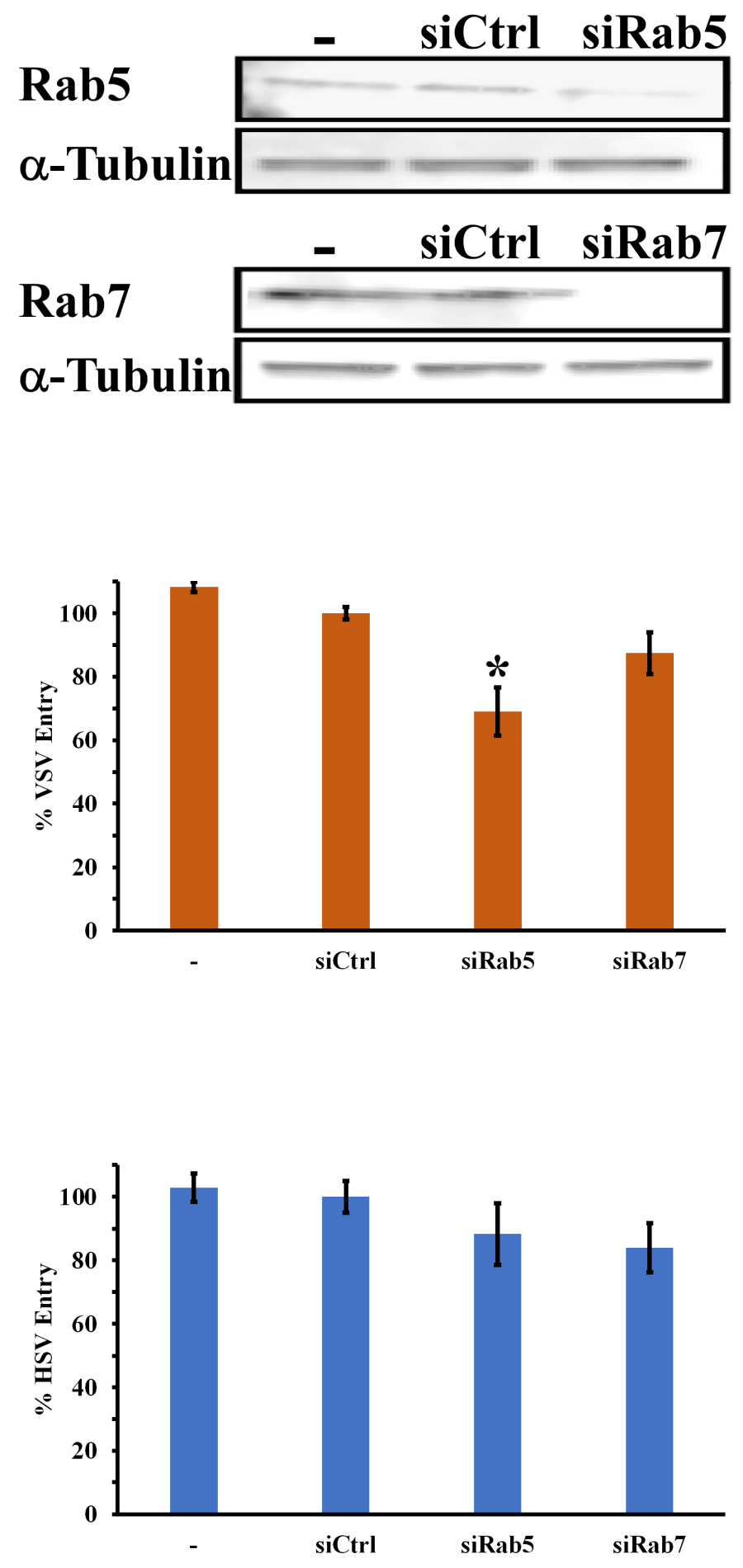

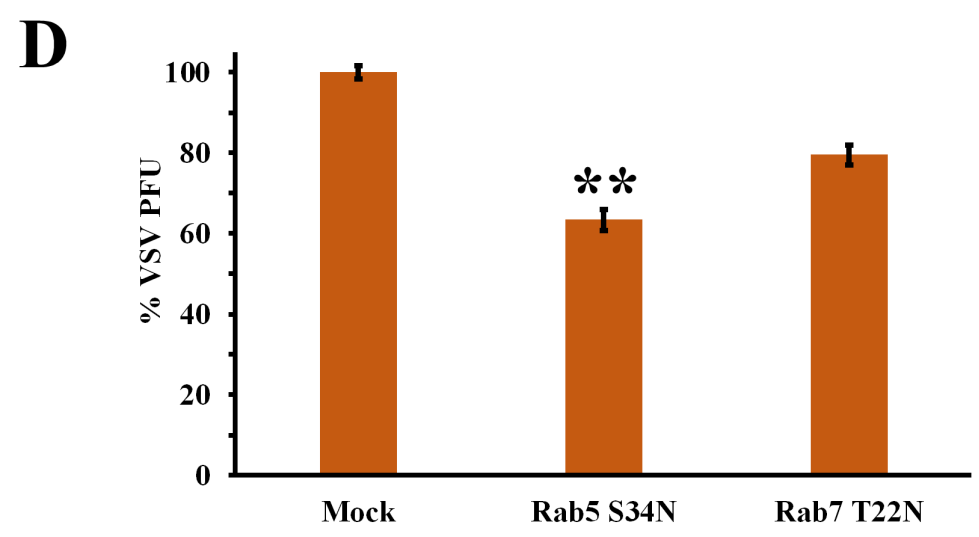

E

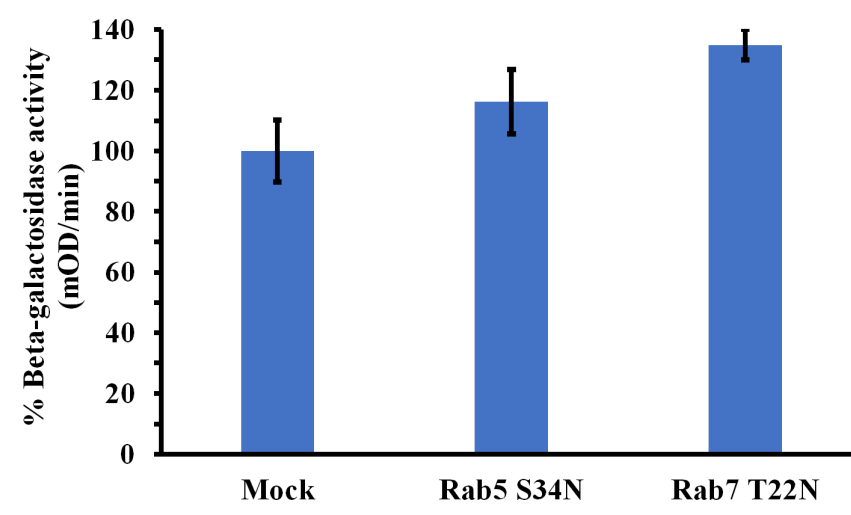


A

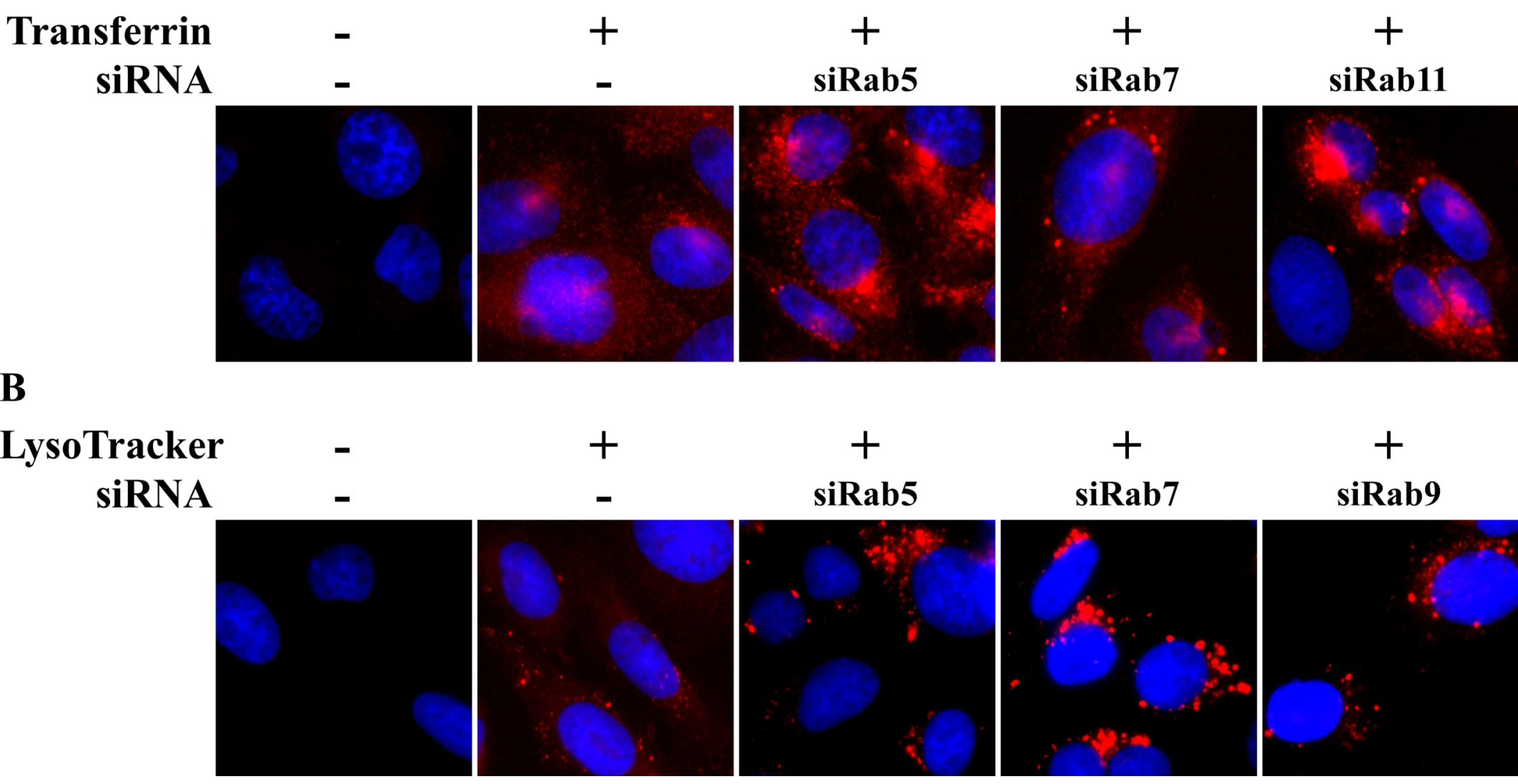




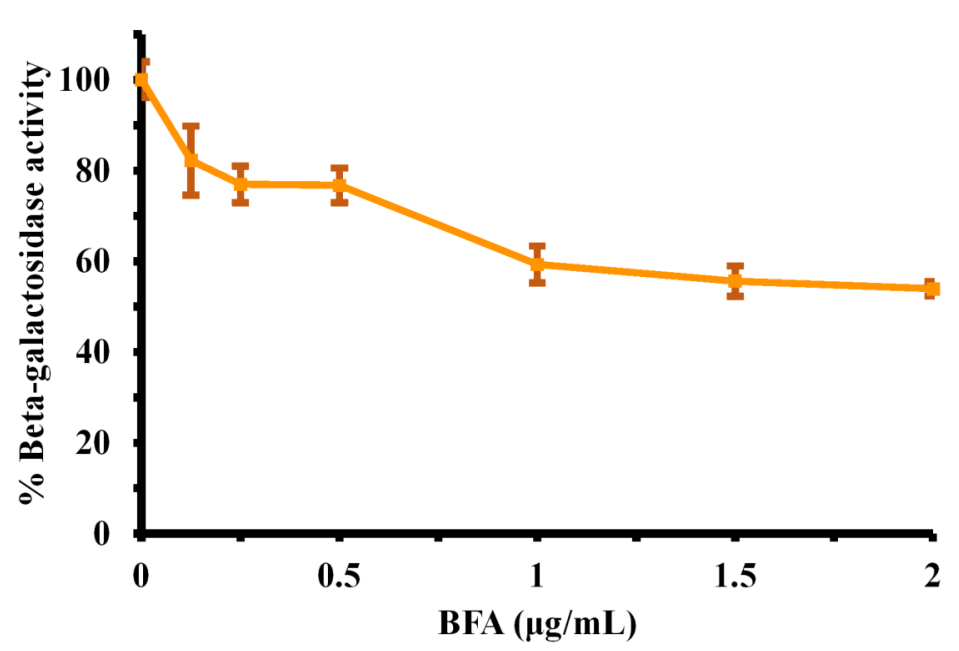

C
No treatment

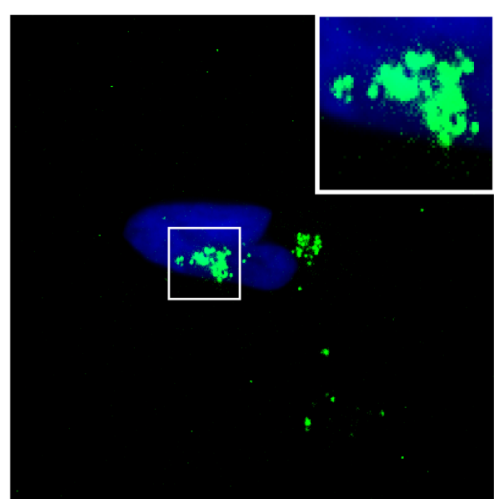

B
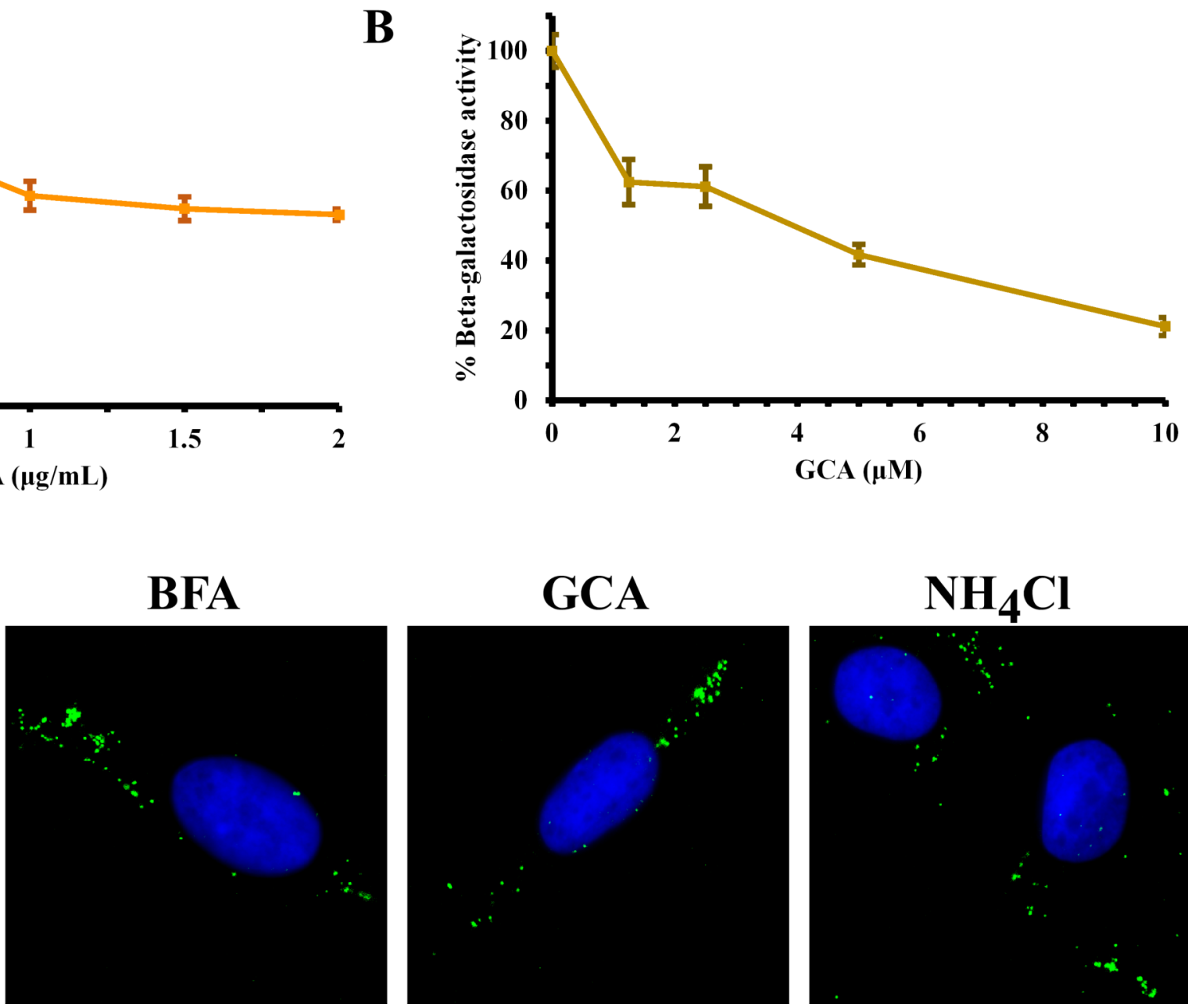

GCA

$\mathrm{NH}_{4} \mathrm{Cl}$

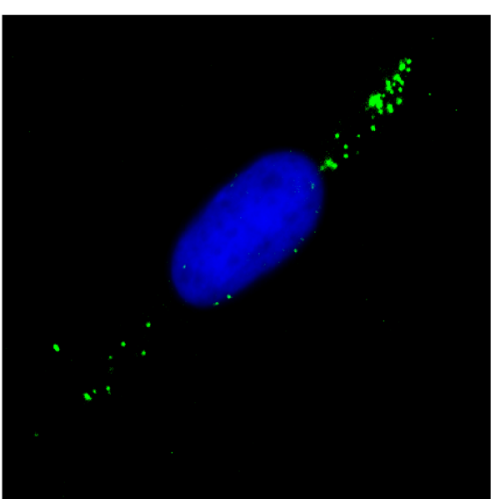

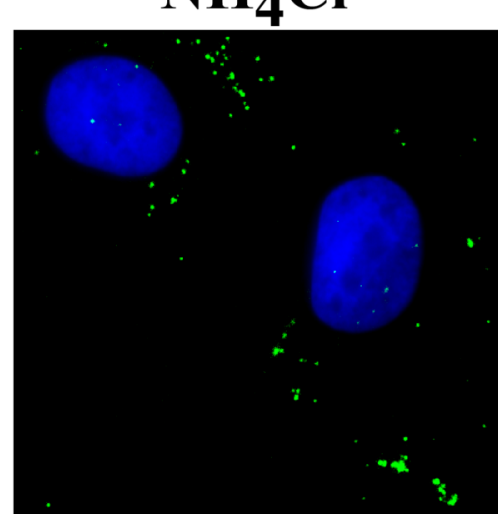



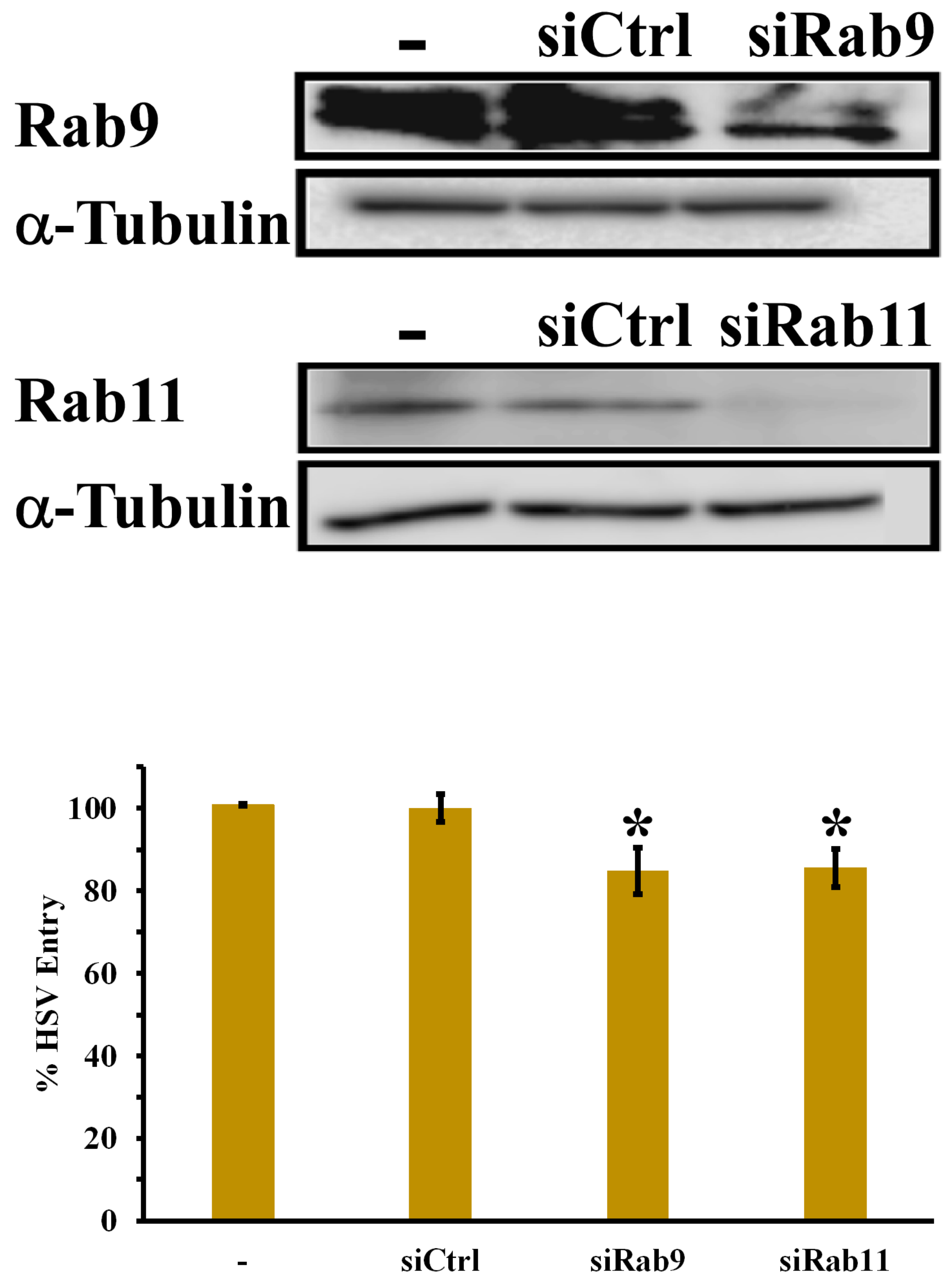


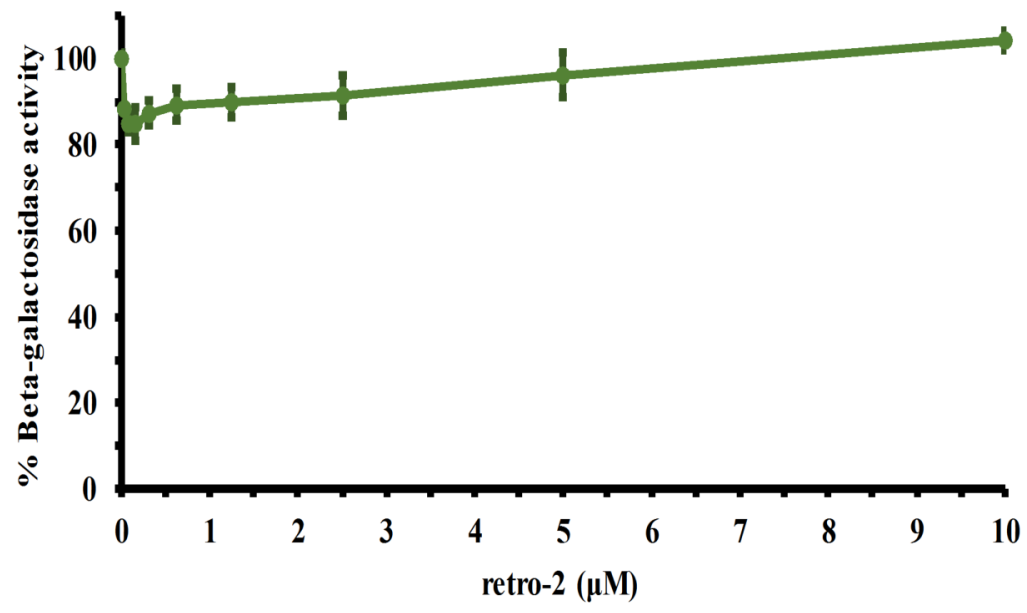

B

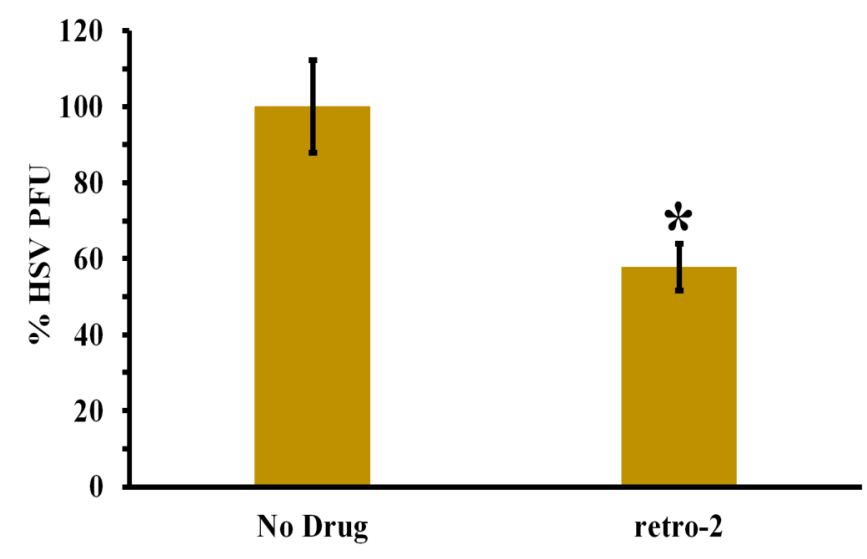

